\title{
DERADIKALISASI PEMBELAJARAN PENDIDIKAN AGAMA ISLAM (PAI) MODEL KEBERAGAMAAN INKLUSIF DIKALANGAN SISWA SMA
}

\author{
ABDURROHMAN \\ Program Studi Pendidikan Sosiologi Universitas Hamzanwadi \\ Lombok Timur NTB \\ Email: armindo.dmk@gmail.com
}

\begin{abstract}
The phenomenon of religious radicalism has become a global threat of the $21^{\text {t }}$ century that phenomenon was a result of Islam as anaccused religion and was often associated with a terrorist religion. Educational institutions often "suspected" in creating of terrorists' generations because the content material of Islamic Religious Education Study was dogmatic, indoctrinated, and related to proselytizing spirit that confirms truth claims. Anyway, substance of instructional materials used in senior high school does not contain inclusive religious content so it can create an exclusive and intolerant religious behavior among senior high school students. The aim of this study; 1).Providing foothold among students of theological and sociological thinking and behavior in order to have an inclusive and tolerant religiosity 2).Deploying and seeding ideas and behavior of an inclusive and tolerant religiosity as a form of resistance ideology (de-radicalization). 3). Filling the void literature Islamic Religious Education Study particular model of inclusive diversity relevant to mainstream Islam in Indonesia. To counteract the religious radicalism among students, the teaching material of Islamic Religious Education Study must contain religious inclusive content incorporating the teachings of Islam as a religion Rahmatan Lil Alamin, a religion of tolerance which is supported by the argument of the Qur'an and hadith. By using this model of teaching materials is expected of senior high school students have an inclusive religious behavior that is relevant to the character and Indonesian Islam mainstream in order to prevent radicalism behavior among senior high school students.
\end{abstract}

Keywords: Islamic Religious Education, Inclusive Diversity, De-Radicalism

\section{Pendahuluan}

Fenomena radikalisme agama telah menjadi perbincangan global yang menarik perhatian dunia pasca tragedi menara kembar World Trade Centre 11 September 2001 silam. Semenjak tragedi itu istilah "radikalisme" sering dikaitkan dengan "terorisme" yang kini menjadi common enemy bagi semua negara di dunia.

Tindakan radikalisme sebagai kejahatan kemanusiaan lintas negara acapkali pelakunya mengatasnamakan jihad dan pembela Islam sehingga berimplikasi pada munculnya stigmatisasi terhadap citra Islam sebagai agama "teroris". Hal ini dapat dipahami 
karena kelompok-kelompok radikal adalah orang-orang Islam yang militan, literalis dengan mengusung ideology jihad (istishhad) dan takfiri (mengkafirkan siapapun yang berbeda faham atau ideologi dengan mereka). Dalam praksis keberagamaan, mereka cenderung eksklusif, intoleransi dalam beragama, anti keragaman sehingga pada titik kritis dihipotesiskan melahirkan terorisme'. Kini gerakan-Islam radikal bermetamorfosis menjadi gerakan radikal baru bernama ISIS (Islamic State of Iraq and Suriah) yang telah menebar ancaman teror global dan aksi kejam tak berprikemanusiaan kepada siapa saja yang dianggap tidak sejalan dengan ideologi dan faham mereka.

Istilah radikalisme berasal dari kata latin, radic yang berarti “akar”, dan radikal adalah (sesuatu yang) bersifat "mendasar" atau hingga ke akar-akarnya. Predikat ini bisa dikenakan pada pemikiran atau paham, sehingga muncul istilah pemikiran yang radikal, dan bisa pula pada gerakan². Berdasarkan hal diatas, radikalisme diartikan sebagai "paham” atau "aliran" yang menginginkan perubahan atau pembaharuan sosial dan politik dengan cara keras atau drastis dan sikap ekstrem disuatu aliran politik ${ }^{3}$. Dengan demikian, Istilah Islam radikal adalah paham keislaman yang menginginkan dilakukannya perubahan sosial-politik sesuai syariat Islam yang dilakukan dengan cara kekerasan ${ }^{4}$.

Di Indonesia gerakan-gerakan keagamaan yang dicap "radikal” mulai bermunculan pasca reformasi tahun 1998. Pada tahun itu tidak hanya terjadi perubahan dibidang politik saja tetapi juga terjadi perubahan pada ranah kehidupan keagamaan yaitu dengan tumbuh suburnya gerakan-gerakan Islam baru non maisnstream ${ }^{5}$. Bentuk gerakan politik dari kelompok non mainstream ini salah satunya ada yang bersifat jihadis yaitu bentuk aksi politik berupa tindakan kekerasan atas nama jihad ${ }^{6}$. Kelompok jihadis ini disinyalir melahirkan gerakan radikalisme yang kemudian melahirkan terorisme di Indonesia seperti peristiwa

1 Mohammad Mahpur, Mencegah Radikalisme, Kompas, 29/12/2012

2 Afif Muhammad, Agama dan Konflik Sosial: Studi Pengalaman Indonesia, (Bandung: Marja, 2013),63

${ }^{3}$ Departemen Pendidikan dan Kebudayaan, Kamus Besar Babasa Indonesia, Jakarta: Balai Pustaka, 2003),919

${ }^{4}$ Afif Muhammad, agama........,63

5 Gerakan-gerakan non mainstream ini mengambil dua bentuk. Pertama, gerakan non salafi yang mengikatkan diri dengan semangat mewujudkan doktrin secara kaffah dalam arti literal. Kedua, Gerakan salafi yang berusaha mewujudkan cita-cita social-politik Islam yang berbeda dengan formulasi gerakan Islam mainstream. Gerakan-gerakan Islam baru non mainstream dalam kelompok nonsalafi di Indonesia seperti Jama'ah tabligh, Darul Arqam, FBI, Hizbut Tahrir dan lain-lain. Sedangkan yang termasuk dalam kelompok Salafi adalah MMI (Majlis Mujahidin Indonesia), Laskar Jihad, Jama'aah Islamiyah Dan-lain-lain, Lihat As'ad Ali Said, Ideologi Gerakan Pasca Reformasi,(Jakarta, LP3ES,20013), 74

${ }^{6}$ Ada 3 bentuk gerakan politik kelompok non mainstream menurut As'ad yaitu, jihadis, reformis, dan rejeksionis lihat As'ad Ali Said 74 
seperti bom Bali I (2002), bom hotel JW Marriot (2003), bom kedutaan Australia (2004), bom Bali II (2006) dan terakhir aksi heroik yang terjadi di Jl. MH Thamrin Jakarta (2016) meski aksi terornya gagal. Tragedi kemanusiaan ini secara drastis telah merusak sendi-sendi keberagaman dan merubah wajah Islam Indonesia menjadi Islam radikal dan intoleran yang semula dikenal sebagai penganut Islam yang ramah dan moderat.

Maraknya aksi dan gerakan radikalisme di Indonesia pasca reformasi disinyalir beberapa pihak sebagai produk pendidikan. Pendidikan "dicurigai" menciptakan generasi teroris kendati institusi pendidikan tidak pernah secara langsung mengajarkan para siswa untuk menjadi teroris, tetapi ada beberapa materi pelajaran Pendidikan Agama (Islam) yang diduga berorama menumbuhkan sifat "sentimen" dan antipati terhadap kelompok lain yang berbeda agama ${ }^{7}$. Dengan kata lain cakupan materi bahan ajar PAI di sekolah-sekolah disinyalir masih bersifat normatif-indoktrinatif, mengarah truth claim, dan belum memuat konten keberagamaan inklusif yang relevan dengan mainstream Islam Indonesia. Model bahan ajar seperti ini akan membentuk cara pandang dan perilaku keberagamaan eksklusif dan intoleran di kalangan siswa. Lagi pula dalam praksis pembelajaran PAI dikelas, banyak ditemukan guru masih mengandalkan metode ceramah yang bersifat indoktrinatif (Teacher Centered Learning). Guru bagaikan da’i yang komunikasinya bersifat satu arah (one way). Disamping itu, guru masih masih terpaku pada penguasaan pengetahuan (transfer of knowledge) belum menyentuh aspek afektif dan psikomotorik dalam proses pembelajaran.

Ada beberapa hasil penelitian yang memperkuat temuan tersebut diantaranya hasil Penelitian Indonesian Institut for society empowerment yang dipublikasikan pada tahun 2015 melaporkan bahwa dari 120 narapidana terorisme yang diwawancarai di 16 LP di 3 negara (Indonesia, Malaysia, dan Filipina), 48,2 \% pelaku berasal dari SMU, jauh lebih besar dibandingkan pelaku yang berasal dari pesantren atau madrasah yang hanya 5,5 dan 3,6\%. Terkait dengan Hal tersebut, Imam besar al-Azhar Ahmed al-Tayeb juga menyerukan reformasi pengajaran agama di Negara-negara Muslim untuk mencegah penyebaran ekstremisme agama. Ia menyebut ekstremisme memiliki korelasi dengan penafsiran yang buruk terhadap al-Qur'an dan Hadist ${ }^{9}$

Hasil penelitian Indonesian Institut for society empowerment dan statemen Ahmed al-Tayeb diatas menjadi dasar kuat bagi peneliti untuk melakukan kajian tentang pembelajaran Pendidikan Agama Islam (PAI) di Sekolah-sekolah Menengah Atas (SMA) se-

\footnotetext{
7 Kompas, $1 / 4 / 2015$

8 Kompas, 10/09/2015

$9 \quad$ Ahmad al-Tayeb, Pengajaran Agama Perlu di Reformasi, (Kompas, 24/2/2015)
} 
kota Selong dengan mengfokuskan kajian pada muatan konten bahan ajar PAI. Sedangkan model Pendidikan Agama (Islam) yang dikembangkan dalam bahan ajar ini adalah model keberagamaan inklusif atau istilah Jack Seymour dan Tabita Kartika Christiani menyebutnya model beyond the wall $^{10}$, atau Richard Martin menyebutnya pendekatan obyektif, positivistik dan realistik ${ }^{11}$. Inti dari keberagamaan ini mengajak para siswa dari beragam agama untuk bekerja sama mengkampanyekan perdamaian, keadilan, kasih sayang, saling toleransi dan keterlibatan mereka dalam kerja-kerja kemanusiaan. Inti dari model keberagamaan ini sama sekali tidak mengkaji agama secara tekstualis-doktrinal yang mengarah pada semangat da'wah yang menegaskan truth claim. Karena musuh agama bukan pemeluk agama yang berbeda, melainkan kemiskinan, kebodohan, kapitalisme, kekerasan, radikalisme, ketidakjujuran, korupsi, manipulasi, kerusakan lingkungan dan sebagainya. Pendekatan ini relevan dengan karakter masyarakat Indonesia yang pluralis dan multireligius ${ }^{12}$.

Mengingat begitu penting dan strategisnya institusi pendidikan sebagai kanal untuk menyebarluaskan paham Islam moderat, maka bahan ajar Pendidikan Agama Islam (PAI) model keberagamaan inklusif menjadi sebuah keniscayaan (dharuriyyat). Dengan model bahan ajar ini diharapkan para siswa memiliki pemikiran dan perilaku keberagamaan yang inklusif dan toleran yang relevan dengan mainstream Islam Indonesia yaitu Islam yang Wasathiah (moderat). Tujuannya untuk mencegah perilaku radikalisme beragama dikalangan siswa (deradikalisasi). Karena penulis yakin bahwa sikap dan perilaku seseorang akan sangat dipengaruhi oleh cara pandangnya (mindset).

\section{Radikalisme Islam}

Tema kajian tentang radikalisme agama pasca tragedi WTC 11 September 2001 telah menjadi isu publik yang tidak hanya ramai diperbincangkan di dunia akademik (the rational world), tetapi telah menjadi kenyataan empirik (the real world). Kejahatan kemanusiaan (humanity crime) yang mengatasnamakan agama ini telah nyata terjadi tidak hanya di Indonesia tetapi juga diberbagai negara di seantero jagad seperti teror di Paris (2015). Umumnya, para pengkaji gerakan Islam menghubungkan radikalisme dengan fundamentalisme yang pada masa-masa sebelumnya justru lebih populer. Artinya istilah Islam radikal sebenarnya muncul belakangan dibanding gerakan atau pemikiran lainnya yang

10 M. Agus Nuryatno, Mengubah Paradigma Pendidikan Agama, (Kompas, 13/1/2012)

${ }^{11}$ Pendapat Martin tersebut dikutip oleh Totok Ariyanto dalam artikelnya berjudul Mengakbiri Hipokrisi Pendidikan Agama, (Kompas, 12/8/2002)

12 Ibid 
lebih dulu dilekatkan kepada Islam, misalnya Islam Militan, Islam Tradisionalis, Islam Modernis, Islam aktual. Akan tetapi pasca tragedi menara kembar WTC 11 september 2001, Istilah "Islam Radikal" telah merebut wacana dalam berbagai pembicaraan dalam skala global ${ }^{13}$

Predikat "radikal sebenarnya sudah cukup lama diberikan kepada, Islam. Mongomery Watt dan Dhilip Hiro yang dikutip Muhammad ${ }^{14}$ menggunakan istilah "radikal" untuk menunjukkan gerakan-gerakan di Mesir yang melakukan berbagai tindak kekerasan, misalnya jama'ah takfir wa al-Hijr, Hizbullah, dan jamaah Al-Jihad.

Terlepas dari perdebatan dalam pemakaian kedua istilah tersebut, gerakan fundamentalisme atau radikalisme sepertinya memiliki "watak keabadian”karena seperti yang dikemukakan azra gerakan radikalisme dipastikan akan muncul sewaktu-waktu dalam system keagamaan, social, budaya, politik yang dipandang tidak menguntungkan Islam dan kaum muslim ${ }^{15}$

Islam radikal merupakan fenomena baru yang menegaskan tentang corak pemahaman dan pengamalan Islam yang khas dan berbeda dari yang lain. Jika pemikiran dan gerakan lain memiliki ciri-ciri tertentu, maka Islam radikal pun memiliki karakteristiknya sendiri. Karakteristik tersebut tidak diperoleh dari tempat kosong, tetapi dari kondisi dan situasi tertentu yang membentuknya. Jika memang demikian, maka memahami Islam radikal tidak mungkin dapat dilepaskan dari pemahaman tentang berbagai situasi dan kondisi yang mengelilinginya ${ }^{16}$.

Terkait dengan tema tersebut, ICG (International crisis Group) yang dikutip Hilmi dalam riset terakhirnya secara hati-hati melakukan pembedaan antara dua kelompok dalam

13 Ada beberapa ilmuawan yang alergi terhadap istilah fundamentalisme dalam menyebut gerakan radikalisme agama seperti John L. Esposito dan Mark Jurgensmeyer. Jurgensmeyer mengemukakan tiga alasan untuk menolak istilah fundamentalisme. 1). Istilah fundamentalisme bersifat merendahkan. Ia menunjuk kepada orang-orang yang memegang literalisme religious yang intoleran, merasa paling benar dan dogmatik. 2) Fundamentalisme merupakan kategori yang tidak tepat untuk membuat perbandingan lintas kultural karena berasal dari tradisi keagamaan protestan. 3). Istilah fundamentalisme cenderung tidak mengandung gerakan politik, dan lebih mementingkan unsur keagamaan ketimbang urusan keduniawian. Sedangkan penolakan Esposito terhadap fundamentalisme adalah 1). Istilah fundamentalisme memiliki pengertian yang terlalu generic karena semua yang menghendaki untuk kembali ke kepercayaan dasar atau dasar-dasar suatu agama dapat dikatakan fundamentalisme. 2). Pengertian dan persepsi tentang fundamentalisme sangat dipengaruhi oleh protestanisme Amerika. 3). Fundamentalisme sering disejajarkan dengan aktifitas politik, ekstrimis, fanatisme, terorisme dan anti Amerika . Lihat Syamsul Arifin, Studi Agama Perspektif Sosiologis dan Isu-isu kontemporer (Malang, UMM Press, 2009), 186

14 Afif Muhammad, Agama dan Konflik. Sosial: Studi Pengalaman Indonesia, (Bandung: Marja, 2013),62

15 Syamsul Arifin..............,184

${ }^{16}$ Ibid, 63 
lanskap Islamisme radikal di Indonesia yaitu; pertama, "Salafi" dan yang kedua "salafi jihad". Kedua aliran yang berbeda ini biasanya memiliki satu kesamaan yaitu di cap "radikal”. ICG mengartikan Salafi sebagai sebuah gerakan reformis muslim yang bertujuan mengembalikan Islam ke dalam bentuknya yang paling murni sebagaimana dipraktekkan oleh Nabi SAW dan sahabat-sahabatnya. Sedangkan salafi jihad diartikan sebagai sayap radikal dari salafisme yang menargetkan musuh-musuh Islam melalui kekerasan khususnya ditujuakan kepada Amerika dan sekutunya ${ }^{17}$

Sedangkan isu yang umum di perbincangkan dalam kajian radikalisme agama menurut Hilmi ${ }^{18}$ adalah faktor apa yang melatarbelakangi kelahiran radikalisme agama? Apakah agama itu sendiri yang by nature mengandung ajaran radikal, ataukah karena faktor hadirnya unsur-unsur diluar agama seperti vested interest dikalangan para pertualang politik yang meminjam agama sebagai kedok untuk memenuhi ambisi dan kepentingan politik mereka?. Pertanyaan ini penting dalam kajian radikalisme agama bukan semata-mata karena agama diyakini memiliki peran strategis dalam proses transformasi sosial-politik-budaya dalam sebuah komunitas, melainkan juga karena efek yang ditimbulkan dari fenomena radikalisme agama seringkali muncul dalam bentuk kekerasan. Terhadap pertanyaan ini muncul dua mazhab pemikiran yang saling bertentangan satu sama lain, yaitu mazhab primordialisme (kulturalisme) dan mazhab instrumentalisme (strukturalisme) ${ }^{19}$

Mazhab primordialisme memiliki asumsi dasar bahwa realitas teks-doktrinal dalam agama harus ditempatkan sebagai variabel independen guna menjelaskan radikalisme agama yang berujung pada tindak kekerasan. Perspektif primordialisme banyak diadopsi oleh para ilmuwan seperti, Samuel K. Huntington, Gilles Kepel, Mark Juergensmeyer, dan Bernard Lewis. Ilmuan-ilmuan tersebut memandang bahwa agamalah yang mempola, membentuk dan memproduksi sebuah entitas peradaban \& kebudayaan. Di abad pasca modern ini, kata mereka, warna peradaban yang akan muncul ke permukaan adalah religion-based; ada peradaban Islam, kristen, Yahudi,Buddha, Hindu, Taoisme dan sebagainya. Berbagai peradaban ini membawa karakter dasar primordialistiknya masing-masing yang tidak bisa dipersatukan dalam sebuah bejana sosial yang heterogen,dan diantara mereka akan terjadi proses kontestasi kuasa yang bisa berujung pada konflik kekerasan. Dalam konteks Islamisme radikal, sejumlah doktrin agama yang tertuang dalam kitab suci seringkali

\footnotetext{
17 Masdar Hilmi, Membaca Agama: Islam Sebagai Realitas terkonstruksi, (Yogyakarta: Kanisius2009),19

${ }^{18}$ Ibid, 45

19 Ibid
} 
“dituduh" sebagai faktor yang harus bertanggungjawab bagi terjadinya aksi vandalisme dan kekerasan, seperti doktrin jihad,doktrin kafir, doktrin supremasi Islam dan lain-lain. Tidak semua faksi Islamisme radikal menggunakan jalur kekerasan untuk memuluskan agenda politiknya. Meski tetap berpijak pada prinsip literalitas dalam memahami teks agama. Faksi ini mengkonstekstualkan doktrin-doktrin diatas dalam kerangka perjuangan (jihad) yang damai). Dalam konteks Islam radikal Indonesia, faksi semacam inilah oleh Sidney Jones diklasifikasikan sebagai kelompok gerakan "salafi murni”. Sementara faksi lain yang cenderung menggunakan jalann kekerasan disebut sebagai "salafi jihad"

Sedangkan yang kedua adalah mazhab Instrumentalisme. Mazhab ini menolak segala klaim primordialisme. Mazhab ini berargumen, doktrin agama bukanlah variabel independen yang bisa "berbicara sendiri", namun ada faktor eksternal diluar agama yang bermain disini.Mazhab ini meyakini ada invisible hand (Meminjam Istilah Adam Smith) yang memanfaatkan sentimen agama untuk kepentingan politik pihak tertentu. Logikanya adakah ajaran agama (Islam) yang by definition mengajarkan konflik kekerasan atau perang antar-agama?, demikian pula agama-agama lain. Oleh karena itu, kaum instrumentalis membalikkan seluruh asumsi teoritis mazhab primordialisme, dengan berpendapat bahwa variabel yang dapat menjelaskan fenomena radikalisme agama adalah variabel "luaran” yang mengelilingi agama, seperti ekonomi, sosial dan politik. Kaum instrumentalis memang tidak menegasikan peran agama dalam arena kehidupan, namun ia lebih mempresentasikan kontestasi kuasa dikalangan komunitas yang secara sosial, ekonomi dan politik mengalami deprivasi. Dikalangan mazhab ini meyakini, kajian radikalisme agama tidak bisa diseret ke wilayah perdebatan dogmatik, tetapi harus dipahami sebagai konsekuensi logis dari distribusi kuasa dan sumber daya yang tidak merata antara masyarakat agama tertentu dengan masyarakat agama lainnya.

Lebih lanjut terkait dengan fenomena terorisme, menurut Qodir $^{20}$ ada masalah dengan Pendidikan Agama yang lebih bercorak formalisme-indoktrinatif, sehingga kurang memberikan ruang refleksi dan kritis pada peserta didik yang mendapatkan pembelajaran terutama sekolah-sekolah berbasis non-agama (sekolah umum) dan belakangan di sekolahsekolah berbasis Agama. Pendidikan agama ini tentu akan terkait dengan pemahaman keagamaan, yaitu adanya keyakinan atas teks agama yang mengajarkan tentang terorisme dari kata jihad. Agama lanjut Qodir, akan menjadi sumber dari terorisme apabila tindakan teror merupakan perwujudan dari perintah Tuhan (teks), baik secara langsung maupun tidak

20 Zuly Qodir, Sosiologi Agama Esay-Esay agama Di Ruang Publik, (Yogyakarta: Pustaka Pelajar, 2011),70 
langsung sebagai persyaratan dalam bentuk-bentuk ritual. Karena secara langsung tidak ada dalil (teks) agama yang menyatakan tentang teror, maka lebih banyak melakukan interpretasi terhadap teks keagamaan seperti jihad, mati syahid dan lain-lain. Dalam hal ini agama bukan merupakan "penyebab" tetapi sebagai "pembenar" atas tindakan-tindakan yang dilakukan oleh para pelaku tindak kekerasan, ancaman dan pembunuhan atas orang lain. Agama di banyak tempat lebih ditempatkan sebagai justifikasi atas perilaku yang dilakukan oleh sekelompok orang atau segelintir orang yang tidak puas dan benci pada kondisi yang terjadi dalam kehidupannya ${ }^{21}$.

\section{Model Pendidikan Agama}

Untuk menjawab model pendidikan agama seperti apa yang memungkinkan melahirkan pribadi yang toleran, penting untuk mempertimbangkan model-model Pendidikan Agama yang dikembangkan Jack Seymour dan Tabita Kartika Christiani ${ }^{22}$. Mereka menjelaskan model-model pendidikan dan pengajaran agama, yaitu in, at, dan beyond the wall.

Pendidikan Agama in the wall berarti hanya mengajarkan agama sesuai agama tersebut tanpa dialog dengan agama lain. Model pendidikan seperti ini berdampak terhadap minimnya wawasan peserta didik terhadap agama lain, yang membuka peluang terjadinya kesalahpahaman dan praduga. Model Pendidikan Agama in the wall juga dapat menumbuhkan superioritas satu agama atas agama yang lain sehingga mempertegas garis demarkasi antara "aku” dan "mereka”

Sikap toleransi, simpati, dan empati terhadap mereka yang beda agama sulit ditumbuhkembangkan dari model pendidikan agama seperti ini. Model pendidikan semacam ini memposisikan agama lain atau penganut agama lain sebagai the others yang akan masuk neraka karena dianggap kafir. Inilah bentuk truth claim yang berdampak pada monopoli Tuhan dan kebenaran. Seakan akan kebenaran dan Tuhan hanya milik individu atau kelompok agama tertentu. Model keberagamaan seperti ini pada gilirannya berkontribusi dalam menanamkan benih-benih eksklusivisme keberagamaan yang berpotensi memicu konflik dan kekerasan atas nama agama. Ironisnya, model pendidikan agama in the wall inilah yang kini mendominasi pendidikan agama di tanah air.

21 Ibid

${ }^{22}$ (Kompas, 13/1/2012). 
Sedangkan Paradigma Pendidikan Agama at the wall tidak hanya mengajarkan agama sendiri, tetapi sudah mendiskusikannya dengan agama lain. Model paradigma pendidikan agama ini merupakan tahap transformasi keyakinan dengan belajar mengapresiasi orang lain yang berbeda agama dan terlibat dalam dialog antaragama.

Sementara Pendidikan Agama beyond the wall tak sekedar berorientasi untuk berdiskusi dan berdialog dengan orang yang berbeda agama. Namun lebih dari itu mengajak peserta didik dari beragam agama untuk bekerja sama mengkampanyekan perdamaian, keadilan, harmoni, dan keterlibatan mereka dalam kerja-kerja kemanusiaan. Semua itu untuk menunjukkan musuh agama bukan pemeluk agama yang berbeda, melainkan kemiskinan, kebodohan, kapitalisme, kekerasan, radikalisme, ketidakjujuran, korupsi, manipulasi, kerusakan lingkungan dan sebagainya. Model pendidikan agama seperti ini juga untuk menunjukkan semua agama mengajarkan kebaikan, dan bahwa agama adalah untuk kebaikan manusia sesuai misi profetiknya. Maka pendidikan agama yang saat ini cenderung eksklusif karena hanya mengajarkan agamanya sendiri (in the wall) perlu digeser kearah inklusif dengan model at dan beyond the wall. Peserta didik tidak hanya kenal agamanya sendiri, tetapi juga bersentuhan dengan agama lain untuk melintasi tradisi lain dan kemudian kembali kepada tradisi sendiri

Sedangkan Totok Ariyanto ${ }^{23}$ dengan mengutip Richard Martin menjelaskan secara elaboratif tentang pola pembelajaran Pendidikan Agama disekolah-sekolah melalui dua yaitu pertama, pendekatan yang bersifat tekstualis, literalis dan skripturalis sehingga menghasilkan seorang believer (mukmin). Kedua, Pendekatan yang bersifat obyektif, positivistik, dan realistik untuk dapat menghasilkan seorang historian atau muarrikh.

Lebih lanjut Ariyanto berargumen, apabila dalam menjelaskan dimensi-dimensi keagamaan dalam pembelajaran Pendidikan Agama menggunakan pendekatan tekstualis, literalis, dan skripturalis maka lebih menitikberatkan pada kebenaran doktrinal dan dogmatis. Pendekatan ini hanya menekankan keunggulan-keunggulan dari sistem nilai, otensitas teks-teks keagamaan serta absolutisme ajaran-ajaran agamanya sendiri. Sementara pada tataran praktis, pendekatan ini banyak menggunakan cara-cara yang bersifat persuasifapologetik. Artinya, disatu sisi ia lebih menonjolkan keunggulan dan kelebihan agamanya sendiri, disisi lain selalu mengorek kelemahan dan mendiskreditkan kekurangan agama lain. Pendekatan agama seperti inilah menurut Ariyanto yang mendominasi penyelenggaraan

${ }^{23}$ Totok Ariyanto, Mengakhiri Hipokrisi Pendidikan Agama, Kompas, 12/8/2002 
Pendidikan Agama di ruang-ruang kelas mulai dari tingkat SD sampai Perguruan Tinggi. Output yang dihasilkan lembaga pendidikan model seperti ini berupa orang-orang yang mudah menafsirkan ayat-ayat suci secara sempit dan kaku dan klaim kebenaran (truth claim) mendasari setiap perilakunya. Dalam hidup bermasyarakat orang-orang seperti ini cenderung bersikap eksklusif, primordialistik. Maka sudah saatnya pola pembelajaran agama seperti ini segera diakhiri, digantikan dengan pola pembelajaran yang sesuai dengan karakter masyarakat Indonesia, yaitu melalui pendekatan yang obyektif, positivistik dan realistik

Pola pendekatan yang terakhir ini berusaha mengurai secara luas dan komprehensif tentang berbagai aspek keagamaan, seperti sejarah, sistem nilai, struktur religi dan doktrinnya serta kontribusinya bagi kehidupan manusia dan kemanusiaan, bukan sama sekali menyalahkan atau membenarkan (value judgement) keagamaan. Pada tataran praksis, pendekatan ini tidak lagi berkutat pada pola pembelajaran ayat-ayat suci dan kewahyuan secara tekstual-literalis, melainkan lebih menekankan pada pemahaman kontekstual sambil mengangkat dan menggali kembali segi-segi “ historis eskegetis” dari teks-teks kitab suci. Dengan menggunakan pendekatan obyektif, postivistik dan realistik ini, orientasi pendidikan agama tidak lagi diarahkan pada upaya pencarian kelemahan dan perbedaan suatu agama. Tetapi lebih dititikberatkan pada upaya pembentukan sikap apresitif positif terhadapa agama lain, seraya tetap mempertahankan sikap otokritik dan introspeksi kreatif terhadap agamanya sendiri. Pendekatan pendidikan agama seperti ini akan dapat membawa pola pemikiran, pemahaman atau penghayatan keimanan seseorang menuju ke corak kehidupan beragama yang inklusif, toleran, dialogis dan kooperatif ${ }^{24}$.

\section{Metode Penelitian}

Desain penelitian yang digunakan dalam penelitian ini mengikuti tahap-tahap Education Research and Development yang biasa disingkat dengan R \& D, karena penelitian ini termasuk ke dalam penelitian pengembangan pendidikan. Metode ini digunakan untuk menghasilkan produk tertentu dan menguji keefektifan produk tersebut. Produk dalam penelitian ini adalah berupa bahan ajar Pendidikan Agama (Islam) model Keberagamaan Inklusif. Produk Bahan ajar yang sudah jadi akan divalidasi oleh ekspert sebelum dilakukan ujicoba

\footnotetext{
${ }^{24}$ Totok Ariyanto, Mengakbiri Hipokrisi Pendidikan Agama, Kompas, 12/8/2002
} 
Lokasi penelitian ini di 5 (Lima) SMA baik Negeri maupun Swasta di Selong dengan rincian 3 (tiga) SMA Negeri dan 2 (dua) SMA Swasta, yaitu SMA Negeri 1 Selong, SMA Negeri 2 Selong, SMA Negeri 3 Selong, SMA Muhammadiyah Selong dan SMA Nahdlatul Wathan (NW) Pancor. Lokasi penelitian ini ditetapkan secara purposive sampling sebagai tempat ujicoba produk agar produk bahan ajar PAI model keberagamaan inklusif yang dihasilkan bisa digunakan di sekolah-sekolah SMA baik Negeri maupun Swasta.

Selanjutnya bahan ajar yang sudah dikembangkan dan divalidasi dilakukan uji coba produk pada sekolah yang dipergunakan sebagai subyek penelitian (Nitiasih dkk, 2013). Hasil dari tahapan ini adalah model Pendidikan Agam Islam model keberagamaan inklusif. Sedangkan Instrumen yang digunakan dalam penelitian ini adalah 1). Lembar observasi. Instrumen ini digunakan untuk mengamati pengelolaan pembelajaran yang dilakukan oleh guru yang mencakup materi Pembelajaran yang disampaikan guru, sumber belajar yang dipakai guru, metode mengajar guru, tugas yang diberikan oleh guru dan karakteristik siswa. 2). Pedoman wawancara. Instrumen ini digunakan untuk mewawancarai guru PAI dan siswa terkait materi (content) PAI, pelaksanaan pembelajarn, tugas, evaluasi dan gambar yang terdapat dalam buku ajar yang digunakan.. Kegiatan observasi dan wawancara ini dilakukan untuk memperoleh informasi tentang masalah yang terkait materi dan pembelajaran PAI di SMA 3). Angket need assessment. Angket ini ditujukan kepada guru PAI untuk memperoleh masukan data kebutuhan tentang cakupan materi PAI model keberagamaan inklusif yang akan digunakan di SMA. Data yang terkumpul kemudian dianalisis dengan menggunakan teknik analisis dekriptif,

Sedangkan Subyek penelitian pengembangan ini adalah Guru Pendidikan Agama Islam (PAI) dan siswa SMA kelas XI se Kecamatan Selong Lombok Timur. Instrumen yang digunakan dalam penelitian ini adalah 1). Lembar observasi. Instrumen ini digunakan untuk mengamati materi Pembelajaran yang disampaikan guru, sumber belajar yang dipakai guru, metode mengajar guru, dan karakteristik siswa. 2). Pedoman wawancara. Instrumen ini digunakan untuk mewawancarai guru PAI dan siswa terkait materi dan pembelajaran PAI. Kegiatan observasi dan wawancara ini dilakukan untuk memperoleh informasi tentang masalah yang terkait materi dan pembelajaran PAI di SMA 3). Angket untuk need assessment. Angket ini ditujukan kepada guru PAI untuk memperoleh data kebutuhan tentang cakupan materi PAI model keberagamaan inklusif yang akan digunakan di SMA. Data yang terkumpul kemudian dianalisis dengan menggunakan teknik analisis dekriptif. 


\section{Hasil Penelitian Dan Pembahasan}

Institusi Pendidikan sedang dalam sorotan besar terkait dengan maraknya terorisme. Indikasinya sangat jelas, beberapa aksi terorisme di Indonesia pelakunya siswa setingkat SMA. Salah satunya adalah bom JW Mariot dan Ritz Charlton melibatkan seorang remaja Dani Dwi Permana $\left(18\right.$ th) ${ }^{25}$. Fenomena ini menunjukkan bahwa siswa-siswa SMA sangat rentan terlibat aksi radikalisme dan terorisme meski jumlahnya masih sangat sedikit. Hal ini karena secara psikologis anak muda mudah terpengaruh oleh hal-hal yang disampaikan oleh orangorang yang dianggap pintar dalam hal keagamaan, apalagi faktor media sosial yang turut membantu anak-anak muda yang mudah berteman dengan siapapun termasuk dengan kelompok-kelompok radikal

PAI merupakan matapelajaran wajib di Sekolah Menengah Atas (SMA) yang harus diikuti oleh seluruh siswa yang beragama Islam. Berdasarkan hasil observasi dan wawancara dilokasi penelitian bahwa pelaksanaan pembelajaran PAI masih mengandalkan metode ceramah (Teacher Centered Learning). Guru bagaikan da’i yang komunikasinya bersifat satu arah. Guru juga masih terpaku pada penguasaan pengetahuan (transfer of knowledge) belum memberikan ruang refleksi kritis pada siswa dalam proses pembelajaran. Disamping itu mayoritas guru PAI belum memiliki wawasan kajian Keislaman kontemporer seperti pluralisme, toleransi, multikulturalisme dan lain-lain. Hal ini terjadi karena sebagian guru matapelajaran PAI disekolah-sekolah memiliki latarbelakang sebagai ustadz. Sedangkan cakupan materi bahan ajar masih bersifat normatif-indoktrinatif, belum memuat konten keberagamaan inklusif yang relevan dengan mainstream Islam Indonesia.

Titik kritis dari bahan ajar PAI yang sarat normative-indoktrinatif ini pada gilirannya akan menumbuhkan perilaku keberagamaan yang cenderung eksklusif, intoleran, berorientasi truth claim sehingga dapat menumbuhkan benih-benih radikalisme dikalangan siswa. Apalagi sebagian besar siswa SMA pengetahuan agamanya masih awam yang notabene rawan tergoda oleh ajakan kelompok radikal. Hal ini terbukti dengan banyaknya para teroris yang tertangkap adalah anak-anak muda yang basis keilmuan agamanya masih awam seperti kalangan siswa SMA. Menurut penelitian Kamaruddin (Direktur Jenderal Pendidikan agama Islam Kemenag) mengatakan ada potenssi radukalisme disekolah lewat pendidikan agama ${ }^{26}$

\footnotetext{
${ }^{25}$ Direktorat Pendidikan Agama Islam, Mewaspadai radikalisme di sekolah, Jakarta,77

${ }^{26}$ Kompas, $11 / 8 / 2015$
} 
Berdasarkan Kondisi pembelajaran PAI diatas, penulis mencoba menyusun bahan ajar Pendidikan Agama Islam model keberagamaan inklusif yang relevan dengan mainstream Islam Indonesia yaitu Islam yang berhaluan Wasathiah (moderat). Tujuannya untuk mencegah perilaku radikalisme beragama dikalangan siswa (deradikalisasi). Bahan ajar Pendidikan agama Islam (PAI) model keberagamaan inklusif ini mengandung muatan yang menegaskan bahwa Islam adalah, agama Rahmatan Lil'alamin yaitu agama yang cinta damai mengajarkan akhlak luhur yang ditunjukkan Nabi SAW, agama yang menghargai perbedaan bukan permusuhan yang diperkuat dengan dalil-dalil al-Qur'an dan hadist.

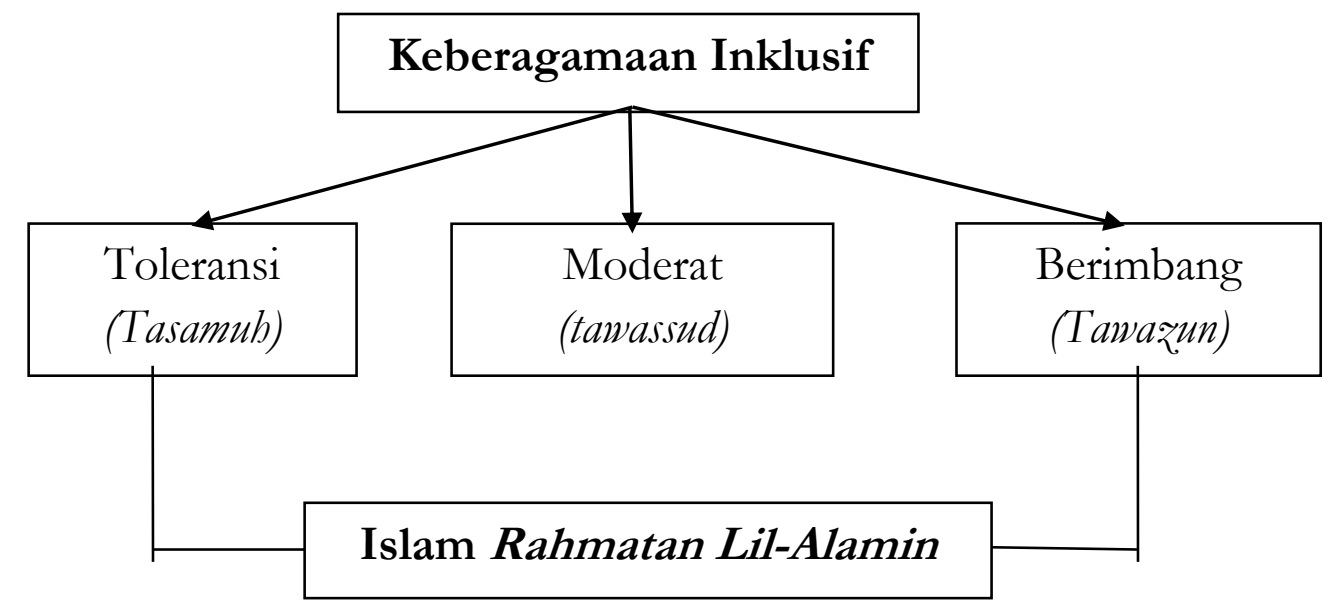

Penulis yakin bahwa sikap dan perilaku seseorang akan sangat dipengaruhi oleh mindset-nya. Berikut ini beberapa tema yang termuat dalam bahan ajar Pendidikan Agam Islam model Keberagamaan inklusif yang terdiri dari tujuh bab:

\begin{tabular}{|c|c|l|}
\hline \multirow{1}{*}{ BAB } & MATERI & \multicolumn{1}{|c|}{ DESKRIPSI } \\
\hline \multirow{1}{*}{ I } & $\begin{array}{c}\text { Islam dan Hak asasi manusia } \\
\text { (al Huquq al-Insaniyyah) }\end{array}$ & $\begin{array}{l}\text { Materi ini menekankan peran Islam dalam } \\
\text { memenuhi hak-hak dasar manusia (huquq al- } \\
\text { Insani). Hak-hak dasar manusia tercakup dalam } \\
\text { lima prinsip dasar yang dikenal dengan ad- } \\
\text { dharuriyyat al-khams atau disebut juga maqashid } \\
\text { as-syari'ah; yakni hifdzhu ad-din (perlindungan } \\
\text { agama), hifdzhu an-nafs (perlindungan diri), } \\
\text { hifdzu al-'aql (perlindungan akal), hifdzhu an-nasl } \\
\text { (perlindungan keluarga), hifdzu al-maal } \\
\text { (perlindungan harta). Lima Hak-hak dasar } \\
\text { manusia yang disebutkan diatas memberi }\end{array}$ \\
\hline
\end{tabular}




\begin{tabular}{|c|c|c|}
\hline & & $\begin{array}{l}\text { pelajaran moral pada kita bahwa manusia adalah } \\
\text { makhluk yang sangat dihormati disemua waktu } \\
\text { dan semua tempat tanpa melihat kebangsaan, } \\
\text { agama, jenis kelamin, warna kulit, status social, } \\
\text { pekerjaan atau karakter etnik, budaya dan } \\
\text { karakter social lainnya. Sebab beragama adalah } \\
\text { memanusiakan manusia serta menghargainya } \\
\text { sebagai ciptaan itulah kodrat Ilahi. }\end{array}$ \\
\hline II & Khilafah & $\begin{array}{l}\text { Bab ini ingin mencoba mengurai benang kusut } \\
\text { hakekat makna khilafah yang sampai sekarang ini } \\
\text { masih menjadi perdebatan dikalangan internal } \\
\text { umat Islam. Bab ini ingin menjelaskan hakekat } \\
\text { makna Khilafah menurut Islam yang diperkuat } \\
\text { dengan dalil al- Qur'an dan hadist }\end{array}$ \\
\hline III & Islam dan toleransi & $\begin{array}{l}\text { Bab ini ingin menghadirkan bahwa Islam adalah } \\
\text { agama toleransi (tasamuh). Islam sebagai agama } \\
\text { yang menjunjung tinggi kedamaian, menghargai } \\
\text { perbedaan sebaliknya mengecam permusuhan } \\
\text { dan kebencian. Bab ini juga akan dipaparkan } \\
\text { teladan Rasulullah dalam hal bertoleransi ketika } \\
\text { beliau hidup di Madinah dimana masyarakatnya } \\
\text { dikenal majemuk kemudian lahirlah sebuah } \\
\text { perjanjian yang dikenal dengan "Piagam } \\
\text { Madinah" }\end{array}$ \\
\hline IV & Etika bergaul & $\begin{array}{l}\text { Bab ini menjelaskan etika bergaul seorang } \\
\text { muslim dalam hidup bermasyarakat. Etika } \\
\text { bergaul ini meliputi pergaulan sesama muslim } \\
\text { dan pergaulan dengan non muslim. Bab ini ingin } \\
\text { menegaskan bahwa dalam hal pergaulan Islam } \\
\text { telah mengajarkan tatacara atau etika dalam } \\
\text { bergaul agar kehidupan manusia bersifat } \\
\text { harmonis dan damai tanpa saling permusuhan } \\
\text { dan menebar kebencian }\end{array}$ \\
\hline
\end{tabular}




\begin{tabular}{|c|c|c|}
\hline V & $\begin{array}{l}\text { Kesalehan Individual dan } \\
\text { Kesalehan sosial }\end{array}$ & $\begin{array}{l}\text { Bab ini ingin menjelaskan pentingnya } \\
\text { keseimbangan hidup dalam menanamkan nilai- } \\
\text { nilai kebaikan yang berbuah pahala. } \\
\text { Mendekatkan diri pada Tuhan tidak hanya } \\
\text { melalui aktifitas ritual ibadah yang bersifat } \\
\text { individual ansich. Tetapi mendekatkan diri pada } \\
\text { Tuhan juga bisa melalui aktifitas social yang dapat } \\
\text { berbuah pahala seperti menghormati perbedaan, } \\
\text { menjunjung tinggi nilai-nilai toleransi, dan cinta } \\
\text { damai dalam hidup bermasyarakat }\end{array}$ \\
\hline VI & $\begin{array}{l}\text { Islam sebagai Agama } \\
\text { Rahmatan Lil-'́alamin }\end{array}$ & $\begin{array}{l}\text { Bab ini menjelaskan bahwa Islam adalah agama } \\
\text { yang diturunkan Allah SWT untuk menjadi } \\
\text { rahmat bagi Alam semesta. Kerahmatan Allah } \\
\text { meliputi seluruh makhluk, baik orang-orang } \\
\text { mukmin maupun orang-orang kafir. Bahkan } \\
\text { seluruh alam semesta (termasuk binatang, } \\
\text { tumbuhan, dan benda-benda mati) ikut } \\
\text { mendapatkan rahmat Allah. Dengan kata lain, } \\
\text { Islam tidak sekedar menjadi rahmat bagi } \\
\text { pengikutnya, tetapi lebih dari itu menjadi rahmat } \\
\text { bagi pengikut agama lain, umat lain dan bahkan } \\
\text { semua makhluk yang diciptakan Tuhan. } \\
\text { konsep Islam rahmatan lil alamin ini menegaskan } \\
\text { bahwa dalam berda'wah Islam tidak mengajarkan } \\
\text { kekerasan dan paksaan dalam beragama. Tetapi } \\
\text { Islam justru mengajarkan kasih sayang kepada } \\
\text { seluruh manusia }\end{array}$ \\
\hline VII & $\begin{array}{c}\text { Perbedaan dalam Islam itu } \\
\text { Rahmat }\end{array}$ & $\begin{array}{l}\text { Bab ini menjelaskan bahwa dalam sejarah Islam } \\
\text { terdapat firqah-firqah (golongan-golongan) } \\
\text { dikalangan umat Islam, dimana satu sama lain } \\
\text { saling bertentangan fahamnya yang sulit untuk } \\
\text { didamaikan, apalagi untuk dipersatukan. Dalam } \\
\text { Bab ini juga akan di bahas aliran-aliran }\end{array}$ \\
\hline
\end{tabular}




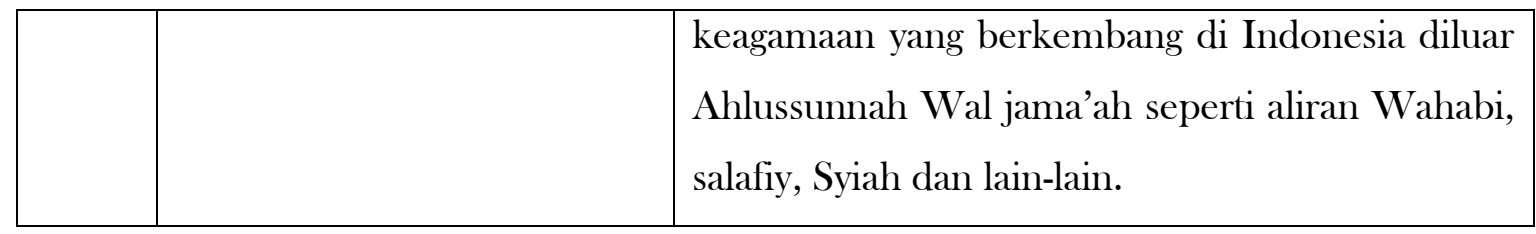

\section{Penutup}

Pelajaran Pendidikan Agama (Islam) di Sekolah Menengah Atas (SMA) merupakan pelajaran yang membahas wilayah nilai (values). Karena Membahas wilayah nilai (value) ,maka Substansi cakupan materinya hitam-putih, literal dan terkesan normatif indoktrinatif tanpa member ruang kritis-reflektis pada siswa dalam proses pembelajaran. Titik tekan normative-indoktrinatif ini pada gilirannya akan menumbuhkan perilaku keberagamaan yang eksklusif, cenderung intoleran, berorientasi truth claim sehingga dapat menumbuhkan benih-benih radikalisme dikalangan siswa. Keberadaan bahan ajar PAI tersebut akan membahayakan kehidupan sosial keagamaan dimasyarakat karena tidak relevan dengan karakter masyarakat Indonesia dan mainstream Islam Indonesia yang mayoritas berhaluan Islam Wasathiyyah (moderat).

Berdasarkan kondisi diatas maka Bahan ajar Pendidikan Agama Islam (PAI) model keberagamaan inklusif ini sangat penting dan strategis karena relevan dengan karakter masyarakat Indonesia yang plural dan mainstream Islam Indonesia yaitu Islam yang Wasathiah (moderat). Bahan ajar ini ingin mempertegas Islam sebagai agama cinta damai, agama Rahmatan Lil 'alamain dan agama toleransi yang diperkuat dengan dalil alqur'an dan hadist. Hal ini dilakukan untuk mencegah radikalisme beragama dikalangan siswa (deradikalisasi) seiring dengan maraknya aktor-aktor radikal (teroris) yang mayoritas masih berstatus kaum muda terpelajar.

\section{Daftar Pustaka}

.Sugiyono, Metode Penelitian Pendidikan Pendekatan Kuantitatif, Kualitatif dan R\&D, Bandung: Alfabeta ,2009

Ali, As’ad Said Ali, , Ideologi Gerakan Pasca Reformasi, Jakarta: LP3ES, 2012

Arifin, Syamsul, Studi Agama Perspektif Sosiologis \& Isu-isu Kontemporer, Malang: UMM Press, 2009 
Ariyanto, Totok, Mengakhiri Hipokrisi Pendidikan Agama, Kompas, 12/8/2002

Borg, W.R Dan Gall M.D, Educational Research: An Introduction, Fifth Edition, New York \& London : Longman, 1989

Departemen Pendidikan Dan Kebudayaan,Kamus Besar Bahasa Indonesia, Jakarta: Edisi 3 Balai Pustaka, 2003

Direktorat Pendidikan Agama Kementerian Agama RI, Mewaspadai Radikalisme Di Sekolah, Jakarta: 2012

Esposito, John P, Islamic Treth: Mith or Reality?, , New York : Oxford University press, 1992 ,

Ghozali, Adeng Muchtar, Agama dan Keberagamaan Dalam Konteks Perbandingan Agama, Bandung: Pustaka Setia, 2004

Hadiz, Vedi R, 2011, Menuju suatu Pemahaman Sosiologis Terhadap Radikalisme Islam di Indonesia, Yogyakarta: Resist Book

Hilmi, Masdar, Membaca Agama: Islam Sebagai Realitas terkonstruksi, Yogyakarta: Kanisius, 2009

Huntington, Samuel P, 1996, The Clash of Civilization and The Remaking of World Order, New York : Simon \& Schuster, 1996

Madjid, Nurcholish, 2008, Islam Doktrin Dan Peradaban, Jakarta : Paramadina, 2008

Mahpur, Mohammad, Mencegah Radikalisme, Kompas, 29/12/2012

Muhammad, Afif, Agama dan Konflik Sosial: Studi Pengalaman Indonesia, Bandung: Marja,2013

Nafis, Muhammad Wahyu, Membangun Islam Inklusif Dalam Kehidupan, Kompas $3 / 8 / 2002$

Nizar, Samsul, Sejarah Sosial Dan dinamika Intelektual Pendidikan Islam Nusantara, Jakarta: Kencana Prenada Media Group, 2013

Nuryatno, M.Agus, Mengubah Paradigma Pendidikan Agama, Kompas 13/01/2012

Qodir,Zuly, Sosiologi Agama Esay-Esay agama Di Ruang Publik, Yogyakarta: Pustaka Pelajar, 2011

Rusman, Model-Model pembelajaran, Mengembangkan Profesionalisme Guru, Jakarta: Rajawali Pers, 2010

Sanjaya,Wina, Strategi pembelajaran Berorientasi Standar Proses Pendidikan. Jakarta : Kencana Predana Media Group, 2007. 